\title{
PROFESIONALISME GURU DALAM PEMERINTAHAN DAERAH
}

\author{
Jan A. Rattu \\ Dosen Jurusan Pendidikan Pancasila dan Kewarganegaraan FIS UNIMA
}

\begin{abstract}
Abstrak
Suatu hal yang tidak dapat dipungkiri bahwa, profesi guru bermakna strategis dalam membangun sumber daya manusia, sebab guru mengemban tugas / amanah dalam proses pemanusiaan, pencerdasan, maupun pembudayaan sekaligus pembentukan karakter bangsa oleh sebab itu pada peringatan hari guru nasional pada tanggal 2 Desember 2004 Presiden mencanangkan bahwa guru sebagai profesi. Peraturan Pemerintah Nomor 19 Tahun 2005 tentang Standar Nasional Pendidikan secara khusus menyangkut standar pendidik disebutkan bahwa kompetensi yang harus dimiliki seorang guru meliputi 1). Kompetensi Pedagogik, 2). Kompetensi Kepribadian, 3). Kompetensi Profesional dan, 4). Kompetensi Sosial
\end{abstract}

Kata Kunci:Profesionalisme, Guru, Pemerintahan Daerah 


\section{A. Pendahuluan}

Suatu hal yang tidak dapat dipungkiri bahwa, profesi guru bermakna strategis dalam membangun sumber daya manusia, sebab guru mengemban tugas / amanah dalam proses pemanusiaan, pencerdasan, maupun pembudayaan sekaligus pembentukan karakter bangsa oleh sebab itu pada peringatan hari guru nasional pada tanggal 2 Desember 2004 Presiden mencanangkan bahwa guru sebagai profesi.

Komitmen pengakuan profesi guru sebagai tenaga professional indikasinya melalui pembuatan Undang-undang Guru dan Dosen serta program sertifikasi pendidik, pengakuan tersebut berfungsi mengangkat martabat dan peran guru sebagai agen pembelajaran. UU Nomor 14 Tahun 2005 tentang Guru dan Dosen menjelaskan bahwa aktualitas tugas dan fungsi penyandang profesi guru berbasis pada prinsip khusus. Prinsip-prinsip khusus dimaksud adalah; 1). Memiliki bakat, minat panggilan jiwa dan idealisme; 2). Memiliki komitmen untuk meningkatkan mutu pendidikan, keimanan, ketakwaan, dan ahlak mulia; 3). Memiliki kualitas akademik dan latar belakang pendidikan sesuai sesuai bidang tugas; 4). Memiliki kompetensi yang diperlukan sesuai bidang tugas; 5). Memiliki tanggung jawab atas pelaksanaan tugas keprofesionalan; 6). Memperoleh penghasilan yang ditentukan sesuai dengan prestasi kerja; 7). Memiliki kesempatan untuk mengembangkan keprofesional secara berkelanjutan dengan belajar sepanjang hayat; 8). Memiliki jaminan perlindungan hokum dalam melaksanakan tugas keprofesionalan; dan 9). Memiliki organisasi profesi yang mempunyai kewenangan mengatur hal-hal yang berkaitan dengan tugas keprofesionalan guru.

Animo lulusan SMA-SMK sekarang ini dalam pengamatan penulis dalam kurun waktu 5 tahun terakhir setelah diberlakukannya sertifikasi guru semakin meningkat, hal ini terlihat dari besarnya pelamar pada Perguruan Tinggi yang memiliki program Kependidikan Guru, kondisi seperti ini sebagai pelaku dalam dunia pendidikan tentu sangat membagakan kita semua namun disatu sisi kita perlu mewaspadai munculnya kekecewaan, setelah menjadi guru dan upayanya dalam mewujudkan nilai-nilai keprofesionalannya tidak mendapat respons yang positif dari pada pengambil keputusan, atau dengan kata lain tidak adanya penghargaan atas profesionalisme guru oleh para pemimpin apalagi tenaga kependidikan guru umumnya adalah pegawai negeri sipil daerah yang tentu tidak dapat lepas dari lingkup pemerintahan daerah atau birokrasi daerah yang selalu dekat dengan kepentingan politik dan yang sering mengabaikan profesionalisme apalagi profesi guru mau tidak mau terlibat dalam percaturan politik karena profesi guru disaat pemilihan kepala daerah atau pemilihan calon legislatif tetap memberikan suara atau memiliki hak suara, situasi pemilihan kepala daerah ataupun pemilihan calon legislatif tidak jarang guru menjadi korban manakala pilihan hatinya tidak sejalan dengan kemauan para pimpinannya indikasinya adalah kalau guru tersebut mendapat tugas tambahan baik sebagai wali kelas, ketua jurusan, ataupun kepala sekolah tugas-tugas tambahan tersebut bisa berpinda tangan kepada orang lain tanpa kajian berdasarkan ketentuan yang berlaku tapi didasarkan pada kepentingan politik.

Sarundajang (2012:3-4), Menyatakan bahwa dalam perkembangannya orang selalu tidak dapat lepas dari pemikiran bahwa baik buruknya birokrasi indentik dengan baik buruknya pemerintah, atau kebobrokan birokrasi adalah kebobrokan pemerintah. Biasanya kebobrokan birokrasi ini bersumber dari mental para birokrat (man behind the gun) yang menciptakan kondisi sedemikian rupa sehingga menimbulkan biaya tinggi dan pemborosan waktu. Lanjut dijelaskan bahwa birokrasi tidak boleh dipolitisasi agar para birokrat dapat melakukan tugasnya dengan fair sesuai dengan kaidah-kaidah manajemen. Namun sayangnya birokrasi di Indonesia dicampuri oleh kepentingan politik.

Jika kita cermati menjadi guru yang professional pada prinsipnya tidak hanya diukur dari guru tersebut telah menerima gaji sertifikasi tapi lebih daripada itu dengan keprofesionalannya yang bersangkutan mendapatkan pembinaan dan pengembangan karir guru meliputi penugasan, kenaikan pangkat dan promosi atau dengan kata lain mendapat tugas tambahan seperti wali kelas, 
ketua jurusan, wakil kepala sekolah, kepala sekolah, ataupun tugas-tugas tambahan lainnya, namun tidak selamanya profesionalisme guru tersebut berbanding sejajar dengan kepentingan politik dalam system pemerintahan daerah disebabkan kepentingan politik menjadi dominan dalam pengambilan keputusan.

\section{B. Profesionalisme Guru}

\section{Pengertian Profesionalisme Guru}

Profesionalisme berasal dari kata profesion, dalam Kamus Inggris Indonesia, "profession berarti pekerjaan" menurut Arifin (1995:3) bahwa profession mengandung arti yang sama dengan kata occupation atau pekerjaan yang memerlukan keahlian yang diperoleh melalui pendidikan atau latihan khusus, hal yang sama juga dikemukakan oleh Kunandar (2007:45) profesionalisme berasal dari kata profesi yang artinya suatu bidang pekerjaan yang ingin atau akan ditekuni oleh seseorang. Profesi juga diartikan sebagai suatu jabatan atau pekerjaan tertentu yang mensyaratkan pengetahuan dan keterampilan khusus yang diperoleh dari pendidikan akademis yang intensif. Jadi, profesi adalah suatu pekerjaan atau jabatan

yang menuntut keahlian tertentu.

Berdasarkan pendapat-pendapat ini, maka dapat ditarik kesimpulan bahwa profesi merupakan pekerjaan atau keahlian yang memerlukan kompetensi intelektualitas, sikap dan keterampilan tertentu yang diperolah melalui proses pendidikan secara akademis. Dengan demikian maka profesi guru menurut Kunandar (2007:47) profesi guru adalah keahlian dan kewenangan khusus dalam bidang pendidikan, pengajaran, dan pelatihan yang ditekuni untuk menjadi mata pencaharian dalam memenuhi kebutuhan hidup yang bersangkutan. Guru sebagai profesi berarti guru sebagai pekerjaan yang mensyaratkan kompetensi (keahlian dan ketrampilan) dan efisien serta berhasil guna.

UU Nomor 14 Tahun 2005 Tentang Guru dan Dosen dalam Bab I Pasal 1 ayat 1 menjelaskan bahwa yang dimaksud dengan guru adalah pendidik professional dengan tugas utama mendidik, mengajar, membimbing, mengarahkan, melatih, menilai dan mengevaluasi peserta didik pada pendidikan anak usia dini, jalur pendidikan formal, pendidikan dasar, dan pendidikan menengah. Selanjutnya pada pasal 1 ayat 4 menyebutkan bahwa professional adalah pekerjaan atau kegiatan yang dilakukan oleh seseorang dan menjadi sumber penghasilan kehidupan yang memerlukan keahlian, kemahiran, atau kecakapan yang memenuhi standar mutu.

Dengan demikian dapat kita katakan, bahwa profesional adalah pekerjaan yang hanya dapat dilakukan oleh mereka yang memang dipersiapkan untuk pekerjaan tertentu dan bukan pekerjaan yang dilakukan oleh mereka yang karena terpaksa melakukan pekerjaan tersebut, bertitik tolak pada pengertian ini, maka pengertian guru profesional adalah seseorang yang memiliki kemampuan, keahlian, ketrampilan khusus dalam bidang keguruan secara akademis.

Tilaar (2002:86) seorang professional menjalankan pekerjaannya sesuai dengan tuntutan profesi atau dengan kata lain memiliki kemampuan dan sikap sesuai dengan tuntutan profesinya. Seorang profesional menjalankan kegiatannya berdasarkan profesionalisme, dan bukan secara amatiran. Profesionalisme bertentangan dengan amatirisme. Seorang professional akan terus-menerus meningkatkan mutu karyanya secara sadar, melalui pendidikan dan pelatihan.

Lebih lanjut Tilaar menjelaskan bahwa Profesionalisme guru merupakan kondisi, arah, nilai, tujuan dan kualitas suatu keahlian dan kewenangan dalam bidang pendidikan dan pengajaran yang berkaitan dengan pekerjaan seseorang yang menjadi mata pencaharian.

Berdasarkan penjelasan-penjelasan sebelumnya dapat disimpulkan bahwa, profesi adalah suatu jabatan, profesional adalah kemampuan atau keahlian dalam memegang suatu jabatan tertentu, sedangkan profesionalisme adalah jiwa dari suatu profesi dan profesional. Dengan demikian, profesionalisme guru adalah kemampuan, keahlian, ketrampilan dalam melaksanakan tugas pokok yang meliputi mendidik, mengajar, membimbing, mengarahkan, melatih, menilai dan mengevaluasi peserta didik, dan memiliki kompetensi kepribadian dan sosial. 


\section{Indikator Kompetensi Profesionalisme Guru dalam Pemerintahan Daerah}

Guru yang professional tentunya memiliki berbagai indicator kompetensi, dalam UU Nomor 14 Tahun 2005 pasal 8 menjeaskan bahwa guru wajib memiliki kualifikasi akademik, kompetensi, sertifikat pendidik, sehat jasmani dan rohani, serta memiliki kemampuan untuk mewujudkan tujuan pendidikan nasional, selanjutnya dalam pasal 10 ayat 1 menjelaskan bahwa kompetensi guru sebagaimana dimaksud dalam pasal 8 meliptui kompetensi pedagogic, kompetensi kepribadian, kompetensi social, dan kompetensi professional yang diperoleh melalui pendidikan profesi.

Peraturan Pemerintah Nomor 19 Tahun 2005 tentang Standar Nasional Pendidikan secara khusus menyangkut standar pendidik disebutkan bahwa kompetensi yang harus dimiliki seorang guru meliputi 1). Kompetensi Pedagogik, 2). Kompetensi Kepribadian, 3). Kompetensi Profesional dan, 4). Kompetensi Sosial, dengan penjelasan sebagai berikut:

a. Kompetensi Pedagogik.

Pasal 28 ayat (3) butir a dikemukakan bahwa kompetensi pedagogik adalah kemapuan mengelola pembelajaran peserta didik yang meliputi pemahaman terhadap peserta didik, perancangan dan pelaksanaan pembelajaran, evaluasi hasil belajar, dan pengembangan peserta didik untuk mengaktualisasikan berbagai potensi yang dimilikinya.

b. Kompetensi Kepribadian.

Pasal 28 ayat (3) butir b, dikemukakan bahwa yang dimaksud dengan kompetensi kepribadian adalah kemampuan kepribadian yang mantap, stabil, dewasa, arif, dan berwibawa, menjadi teladan bagi peserta didik, dan berakhlak mulia.

c. Kompetensi Profesioanal.

Pasal 28 ayat (3) butir c dikemukakan bahwa yang dimaksud kompetensi profesional adalah kemampuan penguasaan materi pembelajaran secara luas dan mendalam yang memungkinkan membimbing pesrta didik memenuhi standar kompetensi yang ditetapkan dalam Standar Nasional Pendidikan.

d. Kompetensi Sosial.
Pasal 28 ayat (3) butir d dikemukakan bahwa yang dimaksud dengan kompetensi social adalah kemampuan guru sebagai bagian dari masyarakat untuk berkomunikasi dan bergaul secara efektif dengan peserta didik, sesama pendidik, tenaga kependidikan, orang tua/wali peserte didik, dan masyarakat sekitar. Dalam Peraturan Menteri Pendidikan Nasional RI No. 16 Tahun. 2007 (Pasal 1 dan 2) mengenai Kualifikasi Akademik dan Kompetensi Guru dijelaskan pula bahwa: Pasal 1 (a). Setiap guru wajib memenuhi standar kualifikasi akademik dan kompetensi guru yang berlaku secara nasional. (b). Standar kualifikasi akademik dan kompetensi guru sebagaimana yang dimaksud pada ayat (1) tercantum dalam Lampiran Peraturan Menteri ini. Pasal 2 Ketentuan mengenai guru dalam jabatan yang belum memenuhi kualifikasi akademik diploma (D-IV) atau Sarjana (S1) akan diatur dengan Peraturan Menteri tersendiri.

Dari pengalaman penulis sebagai guru SMK dari tahun 1985 sampai dengan tahun 2000 (sebelum berlakunya era otonomi daerah), maka kompetensi yang berhubungan dengan tugas guru adalah:

a) Menyusun program pembelajaran

Menyusun/membuat program pembelajaran, merupakan salah satu kompetensi yang harus dimiliki guru karena itu penyusunan program pembelajaran yang dibuat dengan baik memerlukan kompetensi dari seorang guru. Penyusunan program pembelajaran akan tergambar apa yang harus dilakukan guru dan siswa dalam proses pembelajaran lebih daripada itu ke mana siswa akan dibawa (tujuan), apa yang harus siswa pelajari (isi bahan pelajaran), bagaimana cara siswa mempelajarinya (metode dan teknik) dan bagaimana kita mengetahui bahwa siswa telah mencapainya (penilaian).

b) Menguasai bahan pelajaran.

Kemampuan menguasai bahan pelajaran dalam proses pembelajaran, merupakan bagian kompetensi Guru yang mutlak dimiliki dalam mengimplementasi proses pembelajaran. Penguasaan bahan pelajaran ternyata memberikan pengaruh terhadap hasil belajar siswa.

c) Melaksanakan/mengelola proses pembelajaran. 
Melaksanakan atau mengelola program pembelajaran juga membutuhkan kompetensi pada tahap pelaksanaan program yang telah dibuat ini kompetensi yang dibutuhkan menyangkut komitmen guru untuk melaksanakan langkah-langkah proses pembelajaran dituangkan dalam RPP, serta kemampuan keaktifan guru dalam menciptakan dan menumbuhkan kegiatan pembelajaran bagi siswa atau dengan kata lain pemilihan metode pembelajaran yang tepat agar tercipta proses pembelajaran yang aktif, inovatif, kreatif, efektif dan menyenangkan.

d) Melaksanakan penilaian/evaluasi dan analisis hasil penilaian atau evaluasi.

Pelaksanan penilaian atau evaluasi untuk mengetahui sejauhmana kemajuan peserta belajar dalam menguasai materi yang sudah diberikan, sekaligus mengetahui apa yang perlu diperbaiki, terhadap program yang disusun oleh guru atau mengetahui apa yang salah dalam proses pelaksanaan pembelajaran, jadi untuk melakukan hal tersebut seorang guru membutuhkan kompetensi akademik.

Sedangkan berdasarkan pengalaman empiris penulis sebagai birokrat baik sebagai pejabat eselon IV, III dan eselon II di lingkungan Dinas Pendidikan, Pemuda dan Olahraga di dua Kabupaten dari tahun 2001 sampai dengan 2013 diera otonomi daerah, ternyata kompetensi yang harus dimiliki seorang guru disamping kompetensi-kompetensi tugas pokok yang di sebutkan sebelumnya dibutuhkan implementasi kompetensi/kemampuan yaitu kepribadian yang mantap, stabil, arif, dan berwibawa, serta kompetensi/kemampuan social sebagai bagian dari masyarakat untuk berkomunikasi dan bergaul secara efektif dengan masyarakat sekitar.

Kompetensi keperibadian dan sosial bagi seorang guru sangat dibutuhkan diera otonomi daerah atau dalam system pemerintahan daerah oleh karena disetiap agenda politik baik pemilihan Presiden, Gubernur, Bupati, Walikota ataupun DPRD, DPR RI, DPD Hukum Tua umumnya keterlibatan guru dalam Kelompok Panitia Pemungutan Suara (KPPS) atau Panitia Pemungutan Suara (PPS) sangat dominan sekaligus dalam pemberian suara sebagai salah satu hak politik guru, situasi seperti ini memiliki kepekaan konflik social, maupun politik sehingga pada kondisi seperti ini dibutuhkan kompetensi kepribadian yang mantap, stabil, arif dan berwibawa, serta mampu membangun komunikasi yang efektif dengan masyarakat atau dengan pimpinan, sebab jika salah dalam mengambil sikap bisa berujung pada gagalnya profesionalisme yang dibangun dan dimiliki seorang guru.

\section{Sistem Pemerintahan Daerah}

Sistem pemerintahan daerah berhubungan erat dengan istilah otonomi daerah yang biberlakukan di Indonesia. Jika sebelumnya semua sistem pemerintahan bersifat terpusat atau sentralisasi maka setelah diterapkannya otonomi daerah diharapkan daerah bisa mengatur kehidupan pemerintahan daerah sendiri dengan cara mengoptimalkan potensi daerah yang ada.

Meskipun demikian, terdapat beberapa hal tetap diatur oleh pemerintah pusat seperti urusan keuangan negara, agama, hubungan luar negeri, dan lain-lain. Sistem pemerintahan daerah juga sebetulnya merupakan salah satu wujud penyelenggaraan pemerintahan yang efisien dan efektif. Sebab pada umumnya tidak mungkin pemerintah pusat mengurusi semua permasalahan negara yang begitu kompleks. Disisi lain, pemerintahan daerah juga sebagai training ground dan pengembangan demokrasi dalam sebuah kehidupan negara.

Undang-Undang Nomoro 32 tahun 2004 Kelahiran undang-undang ini dilatarbelakangi dengan adanya perkembangan keadaan, ketatanegaraan, dan tuntutan otonomi daerah. dalam penyelenggaraan otonomi menggunakan format otonomi seluas-luasnya. Artinya, azas ini diberlakukan oleh pemerintah seperti pada era sebelum UU Nomor 5 Tahun 1974. Alasan pertimbangan ini didasarkan suatu asumsi bahwa hal-hal mengenai urusan pemerintahan yang dapat dilaksanakan oleh daerah itu sendiri, sangat tepat diberikan kebijakan otonomi sehingga setiap daerah mampu dan mandiri untuk memberikan pelayanan demi meningkatkan kesejahteraan rakyat di daerah.

Pemerintahan Daerah sesuai pasal 1 huruf d Undang Undang Nomor. 22 tahun 1999 
adalah penyelenggara pemerintahan daerah otonom oleh pemerintah daerah dan juga DPRD menurut azaz desentralisasi. Menurut Uundang Undang Nomor. 32 tahun 2004 pada pasal 1 ayat 2, pemerintahan daerah adalah penyelenggaraan urusan pemerintahan oleh pemerintahan daerah dan DPRD menurut asas otonomi dan tugas pembantuan dengan prinsip otonomi yang seluas-luasnya dalam sistem dan prinsip Negara Kesatuan Republik Indonesia sebagaimana dimaksud dalam Undang-Undang Dasar Negara Republik Indonesia Tahun 1945. Pasal 1 ayat $\underline{3}$ Pemerintah daerah adalah Gubernur, Bupati, atau Walikota, dan perangkat daerah sebagai unsur penyelenggara pemerintahan daerah. Pasal 1 ayat 4, Dewan Perwakilan Rakyat Daerah yang selanjutnya disebut DPRD adalah lembaga perwakilan rakyat daerah sebagai unsur penyelenggara pemerintahan daerah.

Penyelenggara pemerintahan daerah adalah pemerintah daerah dan DPRD. Penyelenggaraan pemerintahan berpedoman pada Asas Umum Penyelenggaraan Negara yang terdiri atas asas kepastian hukum, asas kepentingan umum, asas tertib penyelenggara negara, asas proporsionalitas, asas keterbukaan, asas akuntabilitas, asas efektivitas, asas profesionalitas, dan asas efisiensi.

Undang-Undang No. 32 tahun 2004 pasal 1 ayat 5 , pengertian otonomi derah adalah hak ,wewenang, dan kewajiban daerah otonom untuk mengatur dan mengurus sendiri urusan pemerintah dan kepentingan masyarakat setempat sesuai dengan peraturan perundangundangan, sesuai dengan penjelasan UndangUndang No. 32 tahun 2004, bahwa pemberian kewenangan otonomi daerah dan kabupaten / kota didasarkan kepada desentralisasi dalam wujud otonomi yang luas, nyata dan bertanggung jawab. Kewenangan otonomi luas berarti keleluasaan daerah untuk melaksanakan pemerintahan yang meliputi semua aspek pemerintahan kecuali bidang pertahanan keamanan, politik luar negeri, peradilan, agama, moneter \& fiscal serta kewenangan pada aspek lainnya ditetapkan dengan peraturan perundangundangan. Disisi lain keleluasaan otonomi meliputi juga kewenangan yang utuh \& bulat dalam penyelenggaraan mulai dari perencanaan, pelaksanaan, pengawasan, pengendalian hingga evaluasi.

Sesuai dengan UU No. 32 tahun 2004 pasal 1 ayat 7, 8, 9 tentang Pemerintah Daerah, ada 3 dasar sistem hubungan antara pusat \& daerah yaitu: 1). Desentralisasi adalah penyerahan wewenang pemerintah pusat kepada daerah otonom untuk mengatur \& mengurus urusan pemerintah dalam sistem Negara Kesatuan Republik Indonesia. 2). Dekonsentrasi merupakan pelimpahan wewenang pemerintah kepada Gubernur sebagai wakil pemerintah dan/atau kepada instansi vertikal di wilayah tertentu. 3). Tugas perbantuan yaitu penugasan dari pemerintah kepada daerah \& atau desa atau sebutan lain dengan kewajiban melaporkan \& mempertanggung jawabkan pelaksanaannya kepada yang menugaskan.

Berdasarkan penjelasan Undang-Undang No. 32 tahun 2004, prinsip penyelenggaraan otonomi daerah adalah sebagai berikut:

- Penyelenggaraan otonomi daerah dilaksanakan dengan aspek keadilan, demokrasi, pemerataan serta potensi \& keaneka ragaman daerah.

- Pelaksanaan otonomi daerah dilandasi pada otonomi luas, nyata \& bertanggung jawab.

- Pelaksanaan otonomi daerah yang luas \& utuh diletakkan pada daerah \& daerah kota, sedangkan otonomi provinsi merupakan otonomi yang terbatas.

- Pelaksanaan otonomi harus selaras konstitusi negara sehingga tetap terjamin hubungan yang serasi antara pusat \& daerah.

- Pelaksanaan otonomi daerah harus lebih meningkatkan kemandirian daerah kabupaten $\&$ derah kota tidak lagi wilayah administrasi. Begitu juga di kawasan-kawasan khusus yang dibina oleh pemerintah.

- Pelaksanaan otonomi daerah harus lebih meningkatkan peranan \& fungsi badan legislatif daerah baik sebagai fungsi pengawasan, fungsi legislatif, mempunyai fungsi anggaran atas penyelenggaraan otonomi daerah.

- Pelaksanaan dekonsentrasi diletakkan pada daerah propinsi dalam kedudukan sebagai wilayah administrasi untuk melaksanakan 
kewenangan pemerintah tertentu dilimpahkan kepada gubernur sebagai wakil pemerintah.

- Pelaksanaan asas tugas pembantuan dimungkinkan tidak hanya di pemerintah daerah dan daerah kepada desa yang disertai pembiayaan, sarana dan pra sarana serta sumber daya manusia dengan kewajiban melaporkan pelaksanaan dan mempertanggung jawabkan kepada yang menugaskan.

Dalam prakteknya system pemerintahan daerah (otonomi daerah) tidak semanis apa yang diamanatkan dalam Undang-Undang No. 32 tahun 2004, dan peraturan perundang-undangan lainnya terutama dalam pembinaan birokrat, PNS termasuk didalamnya adalah guru, banyak hal yang bisa kita cermati bersama bahwa memasuki era otonomi daerah pembinaan birokrat, PNS baik guru maupun non guru keprofesionalan belum tentu menjadi dasar dalam pengangkatan, penempatan suatu jabatan atau tugas tambahan kepada guru, kasus ini memang dominan terjadi dalam pemerintahan Kabupaten ataupun Kota sebagai contoh penempatan seorang pejabat eselon IV, III, dan II sesuai aturan yang bersangkutan telah memiliki sertifikat kepemimpinan sesuai jabatannya yaitu untuk pejabat eselon IV sudah lulus pendidikan dan pelatihan kepemimpinan tingkat IV, eselon III lulus pendidikan dan pelatihan kepemimpinan tingkat III, dan eselon II lulus pendidikan dan pelatihan kepemimpinan tingkat II atau apabila sudah diangkat minimal 6 bulan menduduki jabatan sudah harus mengikuti Diklat sesuai jabatannya tapi yang terjadi tidak seperti itu artinya keprofesional bukan menjadi factor utama tapi yang utama adalah seberapa besar kontribusi yang bersangkutan dalam pemenangan disaat pilkada ataupun pilcaleg.

Hal yang sama terjadi juga dalam pemberian tugas tambahan kepada guru PNS terutama menjadi kepala sekolah, diera otonomi daerah sekarang ini suatu kemunafikan manakala kita menyangkal bahwa menjadi kepala sekolah kepentingan politik menjadi dominan artinya kepala sekolah sudah termasuk jabatan politik. Dengan demikian kita harus mengatakan bahwa tugas tambahan kepala sekolah di era otonomi daerah umumnya bukan lagi sebagai jabatan profesionalisme.
Sarundajang. (2012:6.7) menyatakan bahwa ... kelihatannya birokrasi di Indonesia belum menyesuaikan diri seperti yang dituntut oleh perubahan lingkungan strategi justru menunjukkan penurunan kualitas birokrasi, terjadi gejala kemandekan birokrasi, selanjutnya beliau memberikan beberapa contoh kasus antara lain: (a). campur tangan politik dalam menentukan jabatan karir seperti Sekretaris Daerah Kabupaten / Kota; (b). isu putera daerah dimana yang menduduki jabatan dalam pemerintahan harus putera daerah; (c). kesulitan mutasi antar daerah otonom atau dari pusat ke daerah otonom, karena alas an gaji tidak termasuk dalam dana alokasi umum (DAU) daerah yang dituju; (d). maraknya isu politik uang, dalam setiap pemilihan gubernur, bupati dan wali kota, serta pada masa pembahasan laporan pertanggungjawaban kepala daerah (LPJ).

\section{Kesimpulan}

1. Profesi guru adalah suatu jabatan yang memerlukan keahlian khusus dan tidak dapat dilakukan oleh sembarang orang diluar bidang kependidikan.

2. Profesionalisme guru adalah kemampuan guru untuk melakukan tugas pokoknya sebagai pendidik dan pengajar meliputi kemampuan merencanakan, melakukan, dan melaksanakan evaluasi pembelajaran untuk mencapai tingkat kedewasaan sebagai tujuan akhir dari proses pendidikan.

3. Tugas seorang guru ada tiga jenis yaitu, tugas guru sebagai profesi,tugas kemanusiaan,tugas dalam bidang kemasyarakatan.

4. Untuk menjadi guru yang professional dalam system pemerintahan daerah harus memiliki dan mengimplementasikan kompetensi profesional yakni, kompetensi pribadi, kompetensi social, kompetensi dalam bidang tugas pokok.

5. Pemberian tugas tambahan kepada guru PNS terutama menjadi kepala sekolah, diera otonomi daerah sekarang ini kepentingan politik menjadi dominan artinya kepala sekolah sudah termasuk jabatan politik.

6. Pemerintahan Daerah adalah penyelenggara pemerintahan daerah otonom oleh 
pemerintah daerah dan juga DPRD menurut azaz desentralisasi, dengan prinsip otonomi yang seluas-luasnya dalam sistem dan prinsip Negara Kesatuan Republik Indonesia

7. Pemerintah daerah adalah Gubernur, Bupati, atau Walikota, dan perangkat daerah sebagai unsur penyelenggara pemerintahan daerah.

8. Profesionalisme guru dalam system pemerintahan daerah tetap harus ditegakkan, dikembangkan dalam pelaksanaan tugas pokok sebagai wujud panggilan jiwa, panggilan hidup yang mulia seorang guru, sekalipun profesionalisme tidak mendapat respon positif para pengambil keputusan/kebijakan di daerah otonom karena kepentingan politik, akan tetapi yang pasti keprofesional dalam mengimplementasikan tugas pokok dalam mendidik, melatih dan membimbing anak bangsa akarnya tidak dapat dicabut pada pribadi seorang guru.

\section{DAFTAR PUSTAKA}

H.A.R. Tilaar, 2002. Membenahi Pendidikan Nasional, Jakarta: PT. Rineka Cipta.

Peraturan Pemerintah RI Nomor 19 Tahun 2005 tentang Standar Nasional Pendidikan. Kementerian Pendidikan Nasional.

Kunandar, 2007. Guru Profesional Implementasi Kurikulum Tingkat Satuan Pendidikan (KTSP) dan Persiapan Menghadapi Sertifikasi Guru, Jakarta: PT Raja Grafindo Persada.

Nana Sudjana, 1988. Dasar-dasar Proses Pembelajaran, (Bandung: Sinar Baru Algesindo.

S.H. Sarundajang 2012. Birokrasi dalam Otonomi Daerah. (upaya mengatasi kegagalan) Jakarta Kata Hasta Pustaka

S.H. Sarundajang 2012. Pemerintahan Daerah di Berbagai Negara. Jakarta Kata Hasta Pustaka
Undang-undang RI Nomor 32 tahun 2004 tentang Pemerintahan Daerah.

Undang-undang RI Nomor 14 tahun 2005 tentang Guru dan Dosen. 